\title{
Comparative Effectiveness of Cognitive Behavioral Therapy 5 Sessions and 12 Sessions Toward to Post Traumatic Stress Disorder on Post Flood Disaster Adolescent
}

\author{
Uray Fretty Hayati ${ }^{1}$, Sari Fatimah ${ }^{2}$, Ai Mardhiyah ${ }^{3}$ \\ ${ }^{1}$ RS Soedarso Kalimantan, ${ }^{2}$ Faculty of Nursing, Padjadjaran University Bandung \\ Email: frettyh@gmail.com
}

Submitted: 5-7-2017 Accepted: 30-4-2018 Published: 30-4-2018

\begin{abstract}
Flood disaster conduced 2375 refugees and traumatic in adolescent with symptoms of Post Traumatic Stress Disorder as many as 15 people in Garut regency. The impact of PTSD on adolescents reduced brain volume, behavioral changed and short-term memory lost. The psychotherapy that proved to be effective overcome PTSD was Cognitive Behavioral Therapy (CBT) 12 sessions but the empirical evidence in Indonesia, the 12 session of CBT intervention was too long, tedious, and caused doubts to the therapist so that 5 session CBT intervention was considered more flexible and efficient. The purpose of this study was compare the effectiveness of PTSD scores pre and post intervention of CBT 5 sessions and 12 sessions toward of PTSD on post flood disaster in adolescent. This research used Quasi Experiment Design with Pre test and Post test approach Two Group Design. The first group was given CBT 5 sessions and the second group was given CBT 12 sessions with the total number of adolescent respondents were 38 people (aged 12-18). The sample was chosen by used Consecutive Sampling at two evacuation sites in Cilawu and Tarogong Kidul subdistrict, Garut regency, West Java, Indonesia. The results of this study pre and post intervention in both groups decreased of PTSD score which difference of median value of 6.00 on CBT 5 session and average difference of 7.58 on CBT 12 session with significancy (p-value $<0.01$ ) and the result analysis test on the effectiveness of both interventions ( $p$-value $>0.05$ ) with significancy number 0.648 . The conclusion was no significant difference between the effectiveness of the CBT group of 5 sessions and the CBT group of 12 sessions. There needs comparison of more than 5 sessions and less than 12 sessions for next research.
\end{abstract}

Keywords: Adolescent, Cognitive Behavioral Therapy (CBT), flood disaster, Post Traumatic Stress Disorder (PTSD). 
Uray Fretty Hayati : Comparative Effectiveness of Cognitive Behavioral Therapy 5 Sessions

\section{Introduction}

Based on the Indonesian Index of Disaster Prone which has been released by BPBD in 2016, Garut regency ranks first as disasterprone areas in the category of Regency/ City in Indonesia because it has 12 types of disaster risk. Flash floods occurred in seven districts in Garut regency which resulted in 2375 people had to evacuate. According to Undang-undang (Indonesian Law) No.24 2007, disaster can be defined as an event or series of events that threaten and disrupt people's lives and livelihoods which caused by natural, non-natural and human factors resulting in human casualties, environmental damage, possessions, and other psychological effects.

Javaid et al. (2011) define the psychological impact as the consequence that occurs because a person is separated from the family members and their care, lack of basic living as well as other psychological impacts. According to Celebi and Metindogan (2010), boys are found to react more aggressively to disasters and externalize behavioral problems, while girls were reported to respond to traumatic events due to disasters with more internalization, which means they are more likely to experience depression.

These psychological impacts are reinforced by Goenjian et al. (2009) who discovered that teenage children in Armenian exposed symptoms of depression after an earthquake occurred in that country 6.5 years ago. This finding is supported by research conducted by Hizli, Taskintuna, Isikli, Kilic, and Zileli (2009) who found symptoms of depression in adolescents that occurred 4 years after the quake in Turkey. This is seen as a subjective experience and a negative perception of the disaster that later developed into PTSD.

PTSD is a profound anxiety disorder and inability accompanied by repetitive trauma symptoms, avoidance behaviour, difficulty sleeping and difficulty concentrating (APA, 2000). According to Mulvihill (2007), disaster experience is a factor that causes trauma symptoms and becomes a stressor. According to the National Center for PTSD (2016), PTSD symptoms are characterized by 3 major symptoms. The first is Re-Experiencing which is the repetition of the experience of trauma (flashback) and nightmares (nightmares). The second is Avoidance: emotions become superficial, avoiding activities and places, thinking, feeling or having conversations related to trauma, or losing interest in all things. The last one is Hyper-Arousal which has 2 or more indications such as difficulty sleeping and difficulty maintaining it, difficulty concentrating, irritability/explosive emotion and shock reaction or excessive alert (Hypervigilance).

The 3 major PTSD symptoms described above are considered to contribute to physical and mental health problems. Mulvihill (2007) states that physical and mental health problems occur because PTSD can employ both short-term and long-term effects. Shortterm effects of PTSD is an increase in cortisol, which then affects immune behaviour and responses. On the other hand, the long-term impact of PTSD results in mental disorders and physical ailments such as irritable bowel syndrome, rheumatoid arthritis and autoimmune disorders.

The view concerning the short-term and long-term effects of PTSD is supported by research conducted by Carrion, Weems, Richert, Hoffman, and Reiss (2010) who found that adolescents aged 10-16 years old with post-traumatic stress symptoms can significantly diminish the amount of brain tissue and prolong cortisol and grey volume of left ventral Frontal Cortex. Research by Carrion et al. (2009) previously also found that adolescents with 10-17 year of age range who experienced post-traumatic stress symptoms also showed the reduced activation of the right hippocampus and the severity of avoidance symptoms, which then correlated with a decrease in the left hippocampus so that the decreasing activity of the hippocampus affects verbal memory.

Another theory regarding PTSD is also presented by Yang et al. (2014), suggests that teenagers with PTSD after 4 months due to natural disasters possess a deficit in emotional control. This statement is similar to the opinion expressed by Zhang, Zhang, Zhu, Du, and Zhang (2015) in a study of adolescents with PTSD after 3 months of earthquakes occurrence. These youths 
Uray Fretty Hayati : Comparative Effectiveness of Cognitive Behavioral Therapy 5 Sessions

showed somatic symptoms of insomnia $(83.2 \%)$, fatigue or lack of energy $(74.4 \%)$, abdominal pain $(63.2 \%)$, dizziness $(58.1 \%)$ and headache $(57.7 \%)$. This is in accordance with the invention proposed by Lanius et al. (2010), which shows that PTSD disorders harm a child's neurobiology, impair the brain function of neurological hypersensitivities such as decreased perception, cognitive and affective, and psychological hypersensitivities such as the disintegration of confidence in life, deficits in short-term memory/mechanic memory areas that will result in severe mental deterioration.

Points to be considered in overcoming PTSD are very important in preventing the emergence of long-term and short-term effects, as well as preventing neurological and psychological damage from these adolescents (Mulvihil, 2007). According to Gillies, Taylor, Gray, O'Brien and D'Abrew (2013) who have conducted 14 meta-analysis studies, state that non-pharmacologic treatment of PTSD in teenagers can be accomplished by conducting CBT therapy that proves to be more significant than other types of psychotherapy. According to Stuart (2016), Cognitive Behavior Therapy (CBT) is one action that can be performed to succeed PTSD problems. Furthermore, according to the National Center for PTSD (2016), CBT can be given to teenagers who suffer PTSD.

Cognitive Behavior Therapy (CBT) is an act that overcomes children's cognitive distortion in order to avoid maladaptive responses from reality misconceptions and improved logic. The findings of research by Kenardy, Cobham, Nixon, McDermott, and March (2010) show that interventions using CBT with the early intervention can reduce symptoms of traumatic stress and prevents chronic disorders as well as disabilities in children with acute PTSD after injury.

Research conducted by Diehle, Opmeer, Boer, Mannarino and Lindauer (2015) on forty-eight school and adolescents (8-18 years old) at the Center de Bascule Amsterdam trauma center with backgrounds on the causes of trauma, the action of CBT showed a substantial decrease from before and after the intervention of hyperactive symptoms which is also a symptom of depression in PTSD.
McMullen, O'callaghan, Shannon, Black, and Eakin (2013) also conducted a study on 50 boys aged $13-17$ who were traumatized by war or engaged in war. After being given the treatment of CBT in the intervention group, there was a very significant reduction in PTSD symptoms such as depression, anxiety symptoms, and aggressive behaviour.

The outcomes of this study are corroborated by former research conducted by Roberts D Clin Psy, Kitchiner, Kenardy, and Bisson (2009) who found that a proven effective CBT technique employed in acute PTSD is 12 Trauma Focus CBT sessions. Similarly, according to O'Donnell et al. (2014) who studied 64 children aged 7-13 years old with post-traumatic stress symptoms at Tanzania Orphanage due to parental loss by giving Trauma Focus CBT 12 sessions. The results of this treatment showed that CBT can decrease sadness and depression significantly with value $(\mathrm{p}<0.01)$.

According to Smith et al. (2007), a decrease of PTSD symptom on $92 \%$ of intervention group can be seen after given the CBT at least 10 weeks. Similarly, research conducted by Cohen (2010) shows that CBT in adolescents give a more significant effect on 12 therapy sessions.

According to Putranto (2016), the old version of CBT therapy by using sessions up to 12 times is not in accordance with Indonesian culture. In his writing, he mentioned that the therapeutic process up to 12 times made the meeting too long, too expensive, complicated, boring and could lower the belief in the therapist ability. This is in line with the opinion expressed by Della (2012); Muqodas (2011) mentions that the cognitive-behaviour therapy counselling process should be adjusted to the existing culture in Indonesia.

In Indonesia, especially in the field of nursing, the duration of CBT therapy in general is 5 sessions. This is evident from a study conducted by Nyumirah (2013) who applied CBT as much as 5 sessions in schizophrenic patients in improving their social interaction ability. Other studies conducted by Sudiatmika, Keliat, and Wardani (2013) compare the effectiveness of $\mathrm{CBT}$ as much as 5 sessions and REBT 
Uray Fretty Hayati : Comparative Effectiveness of Cognitive Behavioral Therapy 5 Sessions

(rational emotive behavior therapy) which finally showed the result of the decrease of violent and hallucinating behavior symptoms as much as p-value $<0.05$, thus CBT and REBT is recommended in nursing orders.

Furthermore, research on disaster-related nursing conducted by Erwina (2010) shows the result of decreasing of PTSD symptoms in the population of age group 20-55 years after the earthquake in West Tawar Barat Village, West Sumatera Province. The result of this study shows a decrease which was seen significantly at $p$-value $<0.05$ after given 5 CBT sessions, but the research of CBT effectiveness in adolescent, especially post-disaster in Indonesia, has never been done.

The phenomenon that occurs in Garut regency, based on the results of the Westaria Bandung Psychology Bureau Study, found that there are several severe trauma conditions in 15 children who lead to symptoms of PTSD after 1 month of flooding (Tarmizi, 2016), even 2 of 15 children should undergo continuous therapy.

Based on the results of this study, the researcher is interested in comparing "whether 5 sessions of Cognitive Behavioral Therapy are more effective than 12 sessions of CBT in diminishing the signs of Post-Traumatic Stress Disorder in Youth Post Disaster Banjir Bandang In Garut District of West Java?", Which is necessary to acknowledge that this study has not been done in previous studies.

\section{Method}

This research was done by using QuasiExperimental Design. The research design is performed by using Pre-test and Post-test of Two Group Design. Methods of the study employed 2 treatment groups. The first group received treatment in the form of 5 sessions cognitive behavioural therapy. The second group received treatment in the form of 12 sessions cognitive behavioural therapy. Before getting the intervention, all groups will be given initial pre-test measurement, and after CBT intervention is done they will be given the post-test measurement to assess the PTSD score. This research was conducted on Garut regency of West Java in teenagers who are in the evacuation area. The duration of the study is 6 weeks which begins on 24 March to 6 May 2017, with the frequency of CBT intervention treatment group 1 and 2 done twice a week, with a duration of 60 minutes in a single meeting.

There are several types of data analysis used in this study, which consists of univariate and bivariate tests.

Univariate Analysis

The researchers conducted Univariate analysis depicting the age of respondents, their gender, education, and factors that caused the respondents to lose their family. The statistical results are in form of mean, median, mode, standard deviation, and proportion of research variables (Supranto, 2007) which then tested homogeneity with Mann Whitney test for age, Chi-Square test for Gender and family loss, and KolmogorovSmirnov test for education.

Bivariate Analysis

This study applied the Bivariate analysis that compares the score of PTSD symptoms based on CPSS on the respondents. In order to comprehend the results of pre-intervention and post CBT intervention in 5 sessions CBT group, it was found that the data were not normally distributed and thus had to use the Wilcoxon test. On the other hand, data were found normally distributed on the 12 sessions CBT group, hence researcher used paired t-test. Thus, in order to compare the effectiveness between the 5-session CBT and the 12-session CBT of both groups by using the Mann Witney test analysis with a statistical significance level of 95\% (alpha = $0.05)$.

\section{Result}

This research was conducted in two shelters of flash floods or banjir bandang victims in the districts of Cilawu and Tarogong Kidul, Garut Regency. The total number of adolescents who still occupied the shelter location were as many as 88 teenagers. This study began on March 24, 2017, and ended on May 6, 2017. The total number of respondents divided into two groups was 38 respondents of adolescents aged 12 to 18 years. The group who were given 5 -session Cognitive 
Uray Fretty Hayati : Comparative Effectiveness of Cognitive Behavioral Therapy 5 Sessions

Behavioral Therapy (CBT) on adolescents as many as 19 respondents and a group given 12-session Cognitive Behavioral Therapy on adolescents as many as 19 respondents.

The data presentation from the results of the research will first describe the characteristics of respondents in the form of percentage for each characteristic. Bivariate analysis explained the difference between mean values of PTSD symptoms before and after CBT intervention in each of the two treatment groups. As for the situation found in the study in adolescents given CBT 5 sessions, the average anxiety of the child was higher than that of the adolescent given CBT 12 sessions. In the implementation process, teenagers who received 5-session CBT still felt less with a 5-session meeting, which was inversely proportional to teenagers getting CBT 12 sessions, from the 10th session of teenagers beginning to show that they were bored.

\section{The Characteristics of Respondents}

Based on the data below, researchers have obtained the results of homogeneity test data based on the characteristics of respondents in the 5-session CBT group and 12-session CBT. It was found that the p-value was > 0.05 , which means there was no difference in the two CBT groups.
The Differences Result of PTSD Score Before and After The Intervention of 5-session CBT and 12-session CBT.

Based on table 2, it can be seen that the median score of PTSD in 5-session CBT group before the intervention was 14.00 (IQR $=6$ ). While in the 12-session CBT group, the PTSD score was $16.32(\mathrm{SD}=5.132)$. The median score after the intervention had been given to 5-session CBT group was 8.00 (IQR $=3$ ), whereas in 12-session CBT group, the average PTSD score was $8.74(\mathrm{SD}=3.314)$. The treatment before and after intervention in both groups was found that there was a decrease of PTSD score, that is the difference of the median value of 6.00 on 5 -session CBT group and the difference of 7.58 mean score on 12-session CBT group.

The results of the analysis on the 5-session CBT group were performed with the Wilcoxon test, with the p-value 0.00 . This value can be interpreted as the difference of PTSD score before and after the 5-session CBT intervention. Similarly, with the analysis result on the 12-session CBT group, there was a difference in PTSD score before and after the 5-session CBT intervention with the significance of $p$ value $=0.00$ performed by paired t-test because the data was normally distributed.

The Result of Scores Differences of Before and After Intervention based on PTSD Symptom Components between 5-session

Table 1 The Distribution of Frequency, Percentage, and Homogeneity Test Respondent Characteristics in 5-Session CBT Group and 12- Session CBT group

\begin{tabular}{|c|c|c|c|c|c|c|}
\hline \multirow[t]{2}{*}{ No } & \multirow[t]{2}{*}{ Characteristics } & \multicolumn{2}{|c|}{ 5-session CBT } & \multicolumn{2}{|c|}{ 12-session CBT } & \multirow[t]{2}{*}{ p value } \\
\hline & & $\mathbf{f}$ & $\%$ & f & $\%$ & \\
\hline \multirow[t]{4}{*}{1} & Age & & & & & \\
\hline & a. Early Youth (12-13 th) & 8 & 42.1 & 6 & 31.6 & $0.767^{\mathrm{b}}$ \\
\hline & b. Middle-age Youth (14-17 th) & 9 & 47.4 & 12 & 63.2 & \\
\hline & $\begin{array}{l}\text { c.Late Youth } \\
(>17 \text { th })\end{array}$ & 2 & 10.5 & 1 & 5.3 & \\
\hline \multirow[t]{3}{*}{2} & Gender & & & & & \\
\hline & a. Boys & 8 & 42.1 & 9 & 47.4 & $0.744^{\mathrm{b}}$ \\
\hline & b. Girls & 11 & 57.9 & 10 & 52.6 & \\
\hline \multirow[t]{4}{*}{3} & Education & & & & & \\
\hline & a. Elementary School & 5 & 26.3 & 3 & 15.8 & $1.000^{\mathrm{c}}$ \\
\hline & b. Junior High School & 7 & 36.8 & 8 & 42.1 & \\
\hline & c. Senior High School & 7 & 36.8 & 8 & 42.1 & \\
\hline
\end{tabular}


Uray Fretty Hayati : Comparative Effectiveness of Cognitive Behavioral Therapy 5 Sessions

\begin{tabular}{|c|c|c|c|c|c|c|}
\hline 4 & The Loss of family member & & & & & \\
\hline & a. Lose & 2 & 10.5 & 4 & 21.1 & $0.660^{\mathrm{b}}$ \\
\hline & b. Not Lose & 17 & 89.5 & 15 & 78.9 & \\
\hline
\end{tabular}
a): p-value was obtained by using Mann Whitney since the data about respondents' age was not normally distributed
b): p-value was obtained by using Chi-Square
c): p-value was obtained by using Kolmogorov-Smirnov Test

Table 2 Differences Result of PTSD Score Before and After The Intervention of 5-Session CBT and 12-Session CBT.

\begin{tabular}{|c|c|c|c|c|c|c|}
\hline \multirow[b]{2}{*}{ Group } & \multirow[b]{2}{*}{ PTSD Score } & \multicolumn{2}{|c|}{ Before } & \multicolumn{2}{|c|}{ After } & \multirow[b]{2}{*}{ p value } \\
\hline & & $\begin{array}{c}\text { Median } \\
\text { Mean }\end{array}$ & $\begin{array}{c}\text { IQR } \\
\text { SD } \\
\end{array}$ & $\begin{array}{c}\text { Median } \\
\text { Mean }\end{array}$ & $\begin{array}{c}\text { IQR } \\
\text { SD }\end{array}$ & \\
\hline 5-session CBT $(n=19)$ & $(0-51)$ & 14.00 & 6 & 8.00 & 3 & $0.00^{\mathrm{a}}$ \\
\hline 12-session CBT $(n=19)$ & $(0-51)$ & 16.32 & 5.132 & 8.74 & 3.314 & $0.00^{\mathrm{b}}$ \\
\hline
\end{tabular}

Table 3 The Differences between The Components of Before and After PTSD Symptoms on 5-Session CBT and 12-Session CBT.

\begin{tabular}{lcccccc}
\hline \multirow{2}{*}{ Group } & \multirow{2}{*}{$\begin{array}{c}\text { The Components of } \\
\text { PTSD Symptoms }\end{array}$} & \multicolumn{2}{c}{ Before } & \multicolumn{2}{c}{ After } & \multirow{2}{*}{ P Value } \\
\cline { 3 - 6 } & & Median & IQR & Median & IQR & \\
\cline { 2 - 5 } & Re-Experience & 6 & SD & Mean & SD & \\
\hline CBT 5 sesi & Avoidance & 5 & 2 & 5 & 3 & $0.000^{\mathrm{a}}$ \\
& Hyperarousal & 3 & 3 & 1 & 3 & $0.003^{\mathrm{a}}$ \\
& Re-Experience & 7 & 5 & 3 & 3 & $0.001^{\mathrm{a}}$ \\
CBT 12 sesi & Avoidance & 5 & 5 & 2 & 3 & $0.002^{\mathrm{a}}$ \\
& Hyperarousal & 5.58 & 2.89 & 3.26 & 2.02 & $0.000^{\mathrm{b}}$ \\
\hline
\end{tabular}

$\mathrm{a}=$ the data was not normally distributed, then it was tested by using the Wilcoxon Test.

$\mathrm{b}=$ it is normally distributed data, then it was tested by using the Paired T-Test.

Table 4 The Results of Differential Test Analysis Score of 5-Session CBT and 12-Session CBT

\begin{tabular}{cccc}
\hline The Analysis Result & $\mathbf{n}$ & $\begin{array}{c}\text { Median } \\
\text { (minimum-maximum) }\end{array}$ & p value \\
\hline 5-session CBT & 19 & $7.00(3-16)$ & 0.648 \\
12-session CBT & 19 & $6.00(3-17)$ & \\
\hline
\end{tabular}

\section{CBT and 12-session CBT.}

Based on table 3 , it is clear that the analysis results of each component of the PTSD symptom (i.e. re-experience, avoidance, and hyperarousal) in both the 5-session CBT group and the 12-session CBT group, there was a significant difference between before and after the intervention. On the other hand, it can be perceived in more detail on each PTSD symptom, that 5-session CBT interventions on the re-experience and hyperarousal components, only the median value decreased, while the median avoidance did not.

In the 12-session CBT intervention group, for each component of the PTSD symptom (ie re-experience, avoidance, hyperarousal), 
Uray Fretty Hayati : Comparative Effectiveness of Cognitive Behavioral Therapy 5 Sessions

it was found that all had decreased.

The Differences in the Effectiveness of 5-session CBT and 12-session CBT on Adolescents with PTSD

In table 4 , since the score of p-value was $>$ 0.05 with significant number 0.648 , it can be concluded that there is no notable difference between the effectiveness of the 5-session CBT group and the 12-session CBT group.

\section{Discussion}

From the results of statistical test analysis in Table 4.4 this study, it is known that there is no difference in the effectiveness between 5 -session CBT group and 12-session CBT group to PTSD adolescent post disaster with the $p$-value of 0.648 . There are several factors that are likely to affect the absence of any difference from these two CBT interventions. The first, when observed from the difference between median and average scores on each 5-session CBT group and 12-session CBT group, the score of 6 and 7.58 did not differ much. Secondly, the teenagers in 5-session CBT group still want the treatment to be extended, while in 12-session CBT group, the teenagers started to feel bored from the 10th session, thus affecting the final result of PTSD score.

The PTSD score differences between 5-session CBT and 12-session CBT was associated to the given $\mathrm{CBT}$ series. In a 5 -session CBT that refers to the FIK-UI module (2009) and was developed by the researchers, it was found that 5-session CBT technique emphasized on two major therapeutic components: cognitive therapy and behavioural therapy. In cognitive therapy, adolescents are taught to train and to overcome their negative thoughts, whereas, in behavioural therapy, adolescents are taught to identify behaviour and develop behaviour plans. In this 5-session CBT group, it can be perceived that more adolescents were affected by PTSD compared to the 12-session CBT group.

Given the number of adolescents who had more PTSD impacts on the outcomes of 5-session CBT, it can be seen that some of the effects of PTSD experienced by adolescents, 18 adolescents $(94.7 \%)$ found it difficult to rejoice, 17 adolescents $(89.5 \%)$ had problems carrying out tasks, and as many as 17 teens $(89.5 \%)$ faced difficulties dealing with their schoolwork. This has an impact so that the need for cognitive and behavioural sessions on a 5-session CBT was insufficient for the respondents. Meanwhile, in a 12-session CBT series developed from the CBT module by Rosello and Bernal (2007), which is a combination of CBT therapy that has been used in depressed adolescents who later investigated CBT trauma-focused PTSD techniques, so the 12-session CBT therapy sequence was not contains only cognitive and behavioral therapies but also therapeutic aspects of adolescent relationships with others, such as teaching assertive techniques, communication exercises, active listening and PTSD explanations for teenage association and PTSD focus trauma.

The above findings can be seen from the results before the intervention of 12-session CBT about the impact of PTSD on the problem of friendship: after being treated by using 12-session CBT, the total number from 9 adolescents $(47.4 \%)$ were decreased to only 1 adolescent $(5.3 \%)$ affected daily PTSD. From this, the researcher then assumed that research needs to see other CBT sessions that are not limited to 5 sessions and 12 sessions, such as 6-session CBT, 8-session CBT and 10-session CBT.

Another factor that contributed to the absence of the difference in the effectiveness of the 5-session CBT and the 12-session CBT, is the teenagers who are in the 5 -session CBT group still wants the process to be continued. While on the other hand, in the 12-session CBT group, starting from the 10th session the adolescents already experiencing boredom that obviously affects the PTSD score outcome. The result of this 12-session CBT intervention then supports the opinion put forward by Putranto (2016) who states that CBT intervention with 12 sessions is considered too long, and will lead to boredom. This is in line with some theories that CBT is a problem-focused therapy, the interaction between mind, emotion, behavior, physical reactions, the environment and one's 
Uray Fretty Hayati : Comparative Effectiveness of Cognitive Behavioral Therapy 5 Sessions

perspective on the problem, with the role of CBT that teaches individuals to identify patterns of negative thinking, their feelings which led to physical reactions and behavior change (Nasir \& Muhith, 2011; Up, 2016). Another theory is that CBT is a pioneer in active therapy, directly on time-limited targets and a structured approach (Sage, Sowden, Chorlton, \& Edeleanu, 2008). Consequently, the success of CBT therapy also involves the respondent's interaction to the given treatment, emphasized that CBT therapy is a therapy that changes people's point of view and the positive mindset to a problem based on the willingness of the respondents themselves.

The results of this study also support the opinion expressed by Erwina (2010), who states that CBT therapy should be flexible, with a varying number of sessions and can be arranged to the needs and objectives of the therapy. Thus, based on the results of this study, the researcher considered the demand for specific instruments to assess the need for the number of times a CBT session could be given according to the PTSD score, as well as the impact that the respondent experienced before determining how many CBT sessions shall be given.

As for the comparison between PTSD score before and after 5-session CBT intervention and 12-session CBT intervention, it was found that 5-session CBT has a significant value equal 0.00 , and 12 -session CBT also holds a significant value equal to 0.00 . The results of the 5-session CBT study were consistent with the previous study conducted by Erwina (2010) which provided 5 sessions of CBT interventions for the respondents aged 20-55 years and obtained a significant p-value of $<0.05$.

It can be seen from the median score of PTSD symptom component (i.e. reexperience, avoidance, hyperarousal) that the median value of avoidance before intervention in the 5-session CBT group is 5. After the intervention, the value is not decreased, still worth 5. This finding, of course, is different from the 12-session CBT intervention group, which for each component of the PTSD symptom (i.e. re-experience, avoidance, and hyperarousal) all of which decreased. This is probably due to anxiety factor in 5-session
CBT respondents which is higher than respondents teens in 12-session CBT.

Furthermore, according to Bryant et al. (2010), the lack of response to CBT intervention is strongly influenced by the feelings of fear or anxiety that existed before the intervention, because the fear affects the amygdala work becomes excessive so that a person with severe anxiety will have difficulty managing his anxiety.

In this research process, the researcher gave intervention on 5-session CBT in overcoming the PTSD symptoms by generating anxiety which is part of CBT technique in dealing with PTSD. CBT itself affects a person in thoughts, feelings, behaviours that mutually influence each other (Manassis, 2009). Nasir and Muhith (2011) also state that CBT therapy concentrates on the problem by cognitive reconstruction so that in giving CBT, a person's perception of an event and mindset deviation are changed towards positive thinking on the willingness of the respondents themselves.

According to Baihaqi (2016), individual's cognitive processes vary from simple to complex. One's cognitive processes include perceptions in detecting and interpreting stimuli from diverse senses at an event, so the perception that a person experiences is a process that forms symbols and settles in his/her mind. It is seen when the provision of CBT therapy about what is felt by teenagers due to flash flood (banjir bandang), so some teenagers leave a sense of fear about the recurrence of that disaster. This then leads to anxiety that is more difficult to overcome by the respondents themselves, thus evolving into avoiding talking about the incidence of disasters that actually affects the anxiety.

In addition to the number of sessions perceived by teenagers, the possibility of other factors that affect non-declining PTSD score is the factor of the severity of avoidance symptoms. According to Carrion et al. (2009), the severity of avoidance symptoms is associated with decreased volume of the left hippocampus. In addition, in the study conducted by Carrion et al. (2009), this has been demonstrated on the basis of MRI imaging studies, so that in adolescents of the 5-session CBT, the investigators assumed it is important to fulfil the need for MRI imaging 
Uray Fretty Hayati : Comparative Effectiveness of Cognitive Behavioral Therapy 5 Sessions

and further medical therapy.

The results of the 12-session CBT group before and after the intervention showed significance $p$-value of 0.00 . In the difference of component of PTSD symptom on the 12-session CBT group, it was known that the median score for re-experience, avoidance, and hyperarousal value have decreased after the intervention with the mean of PTSD before and after the intervention was 7.58 higher than median PTSD value before and after the 5-session CBT intervention with the score of 6.

The results of this study are consistent with preceding studies conducted by Robert (2009) and evidence of the effectiveness of CBT contained in the study of O'Donnell et al. (2014), who states that CBT can be given as many as 12 sessions. There are several factors that play a role in the results of this study. First, the system support factor in 12-session CBT group. Secondly, the impact factor of PTSD in the 12-session CBT adolescence group was smaller compared to the 5-session CBT group.

Based on some existing opinions, it is known that social factors in the form of system support are very influential in strengthening the coping mechanism in a person so that stress and trauma are not prolonged. The support system can be in the form of facilities obtained by the victims (Rusmiyati \& Hikmawati, 2012; Tang, Liu, Liu, Xue, \& Zhang, 2014). The support system obtained by CBT group 12 sessions is that they have occupied the shared house or flat given by the government, even though the location is not in urban, large number of residents, far from school or university, market and other sources. This resulted in adolescents who have adequate support system role in coping mechanism to solve their problems.

The second is a much smaller PTSD impact factor in the 12-member CBT teenage group, as the role of mid-teens more than $12(63.2 \%)$. According to Wilson and Hockenberry (2012), mid-teens have abstract thinking skills that have advanced better, as well as their cognitive function that began to be interested in social problems, politics or philosophy. With the ability to think better abstract then the adolescent will be more capable of solving the problem and they are able to change the negative perception of the disaster experience turned into a positive way of thinking.

The other roles affecting the impact of PTSD are the respondents' gender. This statement is supported by epidemiological findings from Cohen's (2010) study which affirms that adolescent girls aged 12-17 are almost two times higher diagnosed with PTSD than male adolescents. The results of the epidemiology are supported by the opinions of Hamblen and Barnett (2016) which suggest that gender and age have an essential role and that women have double potential trauma due to low serotonin synthesis. Statistically in CBT group of 12 sessions, the percentage of women is lower than the percentage of the 5-session CBT group that is $52.6 \%$ and $57.9 \%$, so it is possible that this factor plays a role in the difference in the decrease in PTSD score.

Based on the results of this study, it has been statistically proven that 5 -session CBT and 12-session CBT interventions have the ability to decrease PTSD score with a significant $p$-value of 0.00 . It is generally related to the cognitive and emotional abilities of teenagers that have developed and completed in the cognitive and emotional abilities of adults so that adolescents are able to spontaneously solve the problem (Piaget, 1972). The cognitive function of the adolescent includes the ability to think abstractly, reasonably, proportionally and solve problems by thinking systematically, thereby making the problem solved at once (Herlina, 2013). Thus, it can be understood that 12-session CBT interventions can be given to post-disaster PTSD adolescents, whereas 5-session CBT not only is given to adult respondents who experience postdisaster PTSD but can also be assigned to adolescents with symptoms of PTSD, especially age 12-18 years with a shorter time and less boredom.

\section{Research Limitation}

As for the limitations of this study, the first is the number of sessions that are still not sufficient for the adolescents in 5-session CBT group. This is likely to affect the score 
Uray Fretty Hayati : Comparative Effectiveness of Cognitive Behavioral Therapy 5 Sessions

that is not much different from the 12-session CBT group. The boredom of teenagers in the 12 -session CBT group that is felt to be too long may affect the final score that is not much different from the CBT group of 5 sessions. Secondly, there is no specific instrument to assess how many sessions should be given and according to the PTSD score as well as the impacts that occur. Thirdly, there are still a few components of undescended symptoms that are not supported by followup examinations such as MRI imaging.

\section{Conclusion}

There was the difference of PTSD score from before and after intervention in 5-session CBT group. From the result of paired statistic test by using Wilcoxon test, it can be seen that there is a significant difference between PTSD score before and after 5-session CBT intervention is given, so it can be concluded that there is a decrease of PTSD score by using 5-session CBT on adolescent who suffered flash floods or banjir bandang in Garut regency, West Java. There was a difference of PTSD score from before and after intervention in 12-session CBT group. The result of paired statistic test by using the paired t-test, it can be perceived that there is significant difference between PTSD score before and after intervention of 5-session CBT, so that it can be concluded that there is a decrease of PTSD score by using 12-session CBT on adolescent who suffered flash floods or banjir bandang in Garut regency, West Java. The results of the effectiveness difference test between the two groups of 5-session CBT and 12-session CBT by using Mann Whitney test that there is no difference of meaning so that the researcher concludes there is no distinction of effectivity between those two. 5-session CBT and 12-session CBT can minimize PTSD scores from the mediocre reaction category to a mild reaction category in which either 5-session CBT and 12-session CBT can be used in chronic phase PTSD adolescents as it can suit client conditions during the intervention and 5-session CBT considered in its use because it is more efficient and does not cause boredom to adolescent clients. For further research, this study can be employed as a basis for comparing CBT interventions in more than 5 sessions and less than 12 sessions, as well as making instruments that specifically examine the needs of CBT sessions according to PTSD scores and their impact.

\section{References}

APA.(2000). Diagnostic and statistical manual of mental disorders. (Rev.) Washington DC: American Psychiatric Association.

Baihaqi, M. (2016). Pengantar psikologi kognitif (Vol. 1). Jakarta: PT. Refika Medika.

BPBD. (2016). Badan Penanggulangan Bencana Daerah Kabupaten Garut. Retrieved 15 Desember, 2016.

Bryant, R.A., Felmingham, K.L., Falconer, E.M., Benito, L.P., Dobson-Stone, C., Pierce, K.D., \& Schofield, P.R. (2010). Preliminary evidence of the short allele of the serotonin transporter gene predicting poor response to cognitive behavior therapy in posttraumatic stress disorder. Biological psychiatry, 67(12), 1217-1219.

Carrion, V.G., Weems, C.F., Richert, K., Hoffman, B.C., \& Reiss, A.L. (2010). Decreased prefrontal cortical volume associated with increased bedtime cortisol in traumatized youth. Biological psychiatry, 68(5), 491-493.

Carrion, V.G., Weems, C.F., Watson, C., Eliez, S., Menon, V., \& Reiss, A.L. (2009). Converging evidence for abnormalities of the prefrontal cortex and evaluation of midsagittal structures in pediatric posttraumatic stress disorder: an MRI study. Psychiatry Research: Neuroimaging, 172(3), 226-234.

Celebi, O., Elif, \& Metindogan, W., Aysegul. (2010). The effects of the 1999 Turkish earthquake on young children: Analyzing traumatized children's completion of short stories. Child development, 81(4), 11611175. 
Uray Fretty Hayati : Comparative Effectiveness of Cognitive Behavioral Therapy 5 Sessions

Cohen, J.A. (2010). Practice parameter for the assessment and treatment of children and adolescents with posttraumatic stress disorder. Journal of the American Academy of Child \& Adolescent Psychiatry, 49(4), 414-430.

Dahlan, M.S. (2010). Besar sampel dan cara pengambilan sampel dalam penelitian kedokteran dan kesehatan (Edisi 2 ed.). Jakarta: Penerbit Salemba Medika.

Della. (2012). Cognitive behavior therapy untuk meningkatkan self esteem pada mahasiswa universitas indonesia yang mengalami distress psikologis. (Pasca Sarjana), Universitas Indonesia, Jakarta. Retrieved from http://lontar.ui.ac.id/opac/ui.

Diehle, J., Opmeer, B.C., Boer, F., Mannarino, A.P., \& Lindauer, R.J. (2015). Traumafocused cognitive behavioral therapy or eye movement desensitization and reprocessing: What works in children with posttraumatic stress symptoms? A Randomized Controlled Trial. European child \& adolescent psychiatry, 24(2), 227-236.

Erwina, I. (2010). Pengaruh Cognitive Behavior Therapy terhadap post traumatic stress disorder pada penduduk pasca gempa Di Kelurahan Air Tawar Barat Kecamatan Padang Utara Provinsi Sumatera Barat. Master Thesis, University of Indonesia, 2012). Diakses dari http://lontar. ui. ac. id/ opac/ui.

Gillies, D., Taylor, F., Gray, C., O’Brien, L., \& D'Abrew, N. (2013). Psychological therapies for the treatment of post $\square$ traumatic stress disorder in children and adolescents (Review). Evidence $\square$ Based Child Health: A Cochrane Review Journal, 8(3), 1004-1116.

Goenjian, A.K., Walling, D., Steinberg, A.M., Roussos, A., Goenjian, H.A., \& Pynoos, R.S. (2009). Depression and PTSD symptoms among bereaved adolescents $6 \frac{1}{2}$ years after the 1988 spitak earthquake. Journal of affective disorders, 112(1), 81-84.

Hamblen, J., \& Barnett, E. (2016). PTSD in children and adolescents. Retrieved 1
Oktober 2016, 2016, from http://www.ptsd. va.gov/professional/treatment/children/ptsd in_children_and_adolescents_overview_for_ professionals.asp.

Herlina. (2013). Mengatasi masalah anak dan remaja melalui buku. Bandung: Pustaka Cendekia Utama.

Hizli, F.G., Taskintuna, N., Isikli, S., Kilic, C., \&Zileli, L. (2009). Predictors of posttraumatic stress in children and adolescents. Children and Youth Services Review, 31(3), 349-354.

Javaid, Z., Arshad, M., \& Khalid, A. (2011). Child protection in disaster management in South Asia: A case study of Pakistan. South Asian Studies, 26(1), 191.

Kenardy, J., Cobham, V., Nixon, R.D., McDermott, B., \& March, S. (2010). Protocol for a randomised controlled trial of risk screening and early intervention comparing child-and family-focused cognitivebehavioural therapy for PTSD in children following accidental injury. BMC psychiatry, 10(1), 92 .

Lanius, R.A., Vermetten, E., Loewenstein, R.J., Brand, B., Schmahl, C., Bremner, J.D., \& Spiegel, D. (2010). Emotion modulation in PTSD: Clinical and neurobiological evidence for a dissociative subtype. American Journal of Psychiatry, 167(6), 640-647.

Manassis, K. (2009). Cognitive Behavioral Therapy with children. A guide for community practitioner New York: Routledge Taylor \& Francis Group.

McMullen, J., O'callaghan, P., Shannon, C., Black, A., \& Eakin, J. (2013). Group trauma $\square$ focused cognitive $\square$ behavioural therapy with former child soldiers and other war $\square$ affected boys in the DR Congo: A randomised controlled trial. Journal of Child Psychology and Psychiatry, 54(11), 1231-1241.

Mulvihill, D. (2007). Nursing care of children after a traumatic incident. Issues in comprehensive pediatric nursing, 30(1-2), $15-28$. 
Uray Fretty Hayati : Comparative Effectiveness of Cognitive Behavioral Therapy 5 Sessions

Muqodas, I. (2011). Cognitive-Behaviour Theraphy: Solusi Pendekatan Praktek Konseling di Indonesia.

Nasir, A., \& Muhith, A. (2011). Dasar-dasar keperawatan jiwa: Pengantar dan teori. Jakarta: Penerbit Salemba Medika.

National Center for PTSD. (2016). Retrieved 30 September 2016, from http://www. ptsd.va.gov/professional/trauma/disasterterrorism/traumatic-effects-disasters.asp.

Nyumirah, S. (2013). Peningkatan kemampuan interaksi sosial (kognitif, afektif dan perilaku) melalui penerapan terapi perilaku kognitif di rsj dr amino gondohutomo semarang. Jurnal keperawatan jiwa, 1(2).

O’Donnell, K., Dorsey, S., Gong, W., Ostermann, J., Whetten, R., Cohen, J. A., . . . Whetten, K. (2014). Treating maladaptive grief and posttraumatic stress symptoms in orphaned children in Tanzania: Group $\square$ based trauma $\square$ focused cognitive-behavioral therapy. Journal of traumatic stress, 27(6), 664-671.

Piaget, J. (1972). Intellectual evolution from adolescence to adulthood. Human development, 15(1), 1-12.

Putranto, K. (2016). Aplikasi cognitive behavior dan behavior acrtivation dalam intervensi klinis. Jakarta Selatan: Grafindo Books Media.

Roberts D Clin Psy, N.P., Kitchiner, N.J., Kenardy, J., \& Bisson, J.. (2009). Systematic review and meta-analysis of multiple-session early interventions following traumatic events. American Journal of Psychiatry, 166(3), 293-301.

Rosello, J., \& Bernal, G. (2007). Treatment manual for cognitive behavioral theapy for depression. Adaptation for Puertorican Adolescents. Rio Piedras: University of Puerto Rico.

Rusmiyati, C., \& Hikmawati, E. (2012). Penanganan dampak sosial psikologis korban bencana Merapi.
Sage, N., Sowden, M., Chorlton, E., \& Edeleanu, A. (2008). CBT for Chronic Illness and Palliative Care. A Workbook and Toolkit. England: John Wiley.

Smith, P., Yule, W., Perrin, S., Tranah, T., Dalgleish, T., \& Clark, D.M. (2007). Cognitive-behavioral therapy for PTSD in children and adolescents: A preliminary randomized controlled trial. Journal of the American Academy of Child \& Adolescent Psychiatry, 46(8), 1051-1061.

Stuart, G.W. (2016). Prinsip dan praktik keperawatan kesehatan jiwa Stuart (B. A. Keliat Ed. Vol. Vol 2): Elsevier.

Sudiatmika, I.K., Keliat, B.A., \& Wardani, I.Y. (2013). Efektivitas cognitive behaviour therapy dan rational emotive behaviour therapy terhadap gejala dan kemampuan mengontrol emosi pada klien perilaku kekerasan. Jurnal Keperawatan Jiwa, 1(1).

Supranto, J. (2007). Statistik teori dan aplikasi (Edisi Ketujuh ed.). Jakarta: Salemba Medika.

Tang, B., Liu, X., Liu, Y., Xue, C., \& Zhang, L. (2014). A meta-analysis of risk factors for depression in adults and children after natural disasters. BMC public health, 14(1), 623.

Tarmizi, T. (2016). Psikolog: Banyak korban banjir bandang Garut trauma berat. ANTARA News.

Undang-Undang (Indonesian Law) No. 24. (2007).

Up, T. W. (2016). Cognitive behavioural therapy course. Retrieved 2 November, 2016, from https://thiswayup.org.au/returningclinicians/cognitive-behavioural-therapy/.

Wilson, D., \& Hockenberry, M.J. (2012). Wong's Clinical Manual Of Pediatric Nursing , 8. United State of America: Elsevier.

Yang, R., Xiang, Y.T., Shuai, L., Qian, Y., Lai, K.Y., Ungvari, G.S., . . . Wang, Y.F. (2014). Executive function in children and 
Uray Fretty Hayati : Comparative Effectiveness of Cognitive Behavioral Therapy 5 Sessions

adolescents with posttraumatic stress disorder 4 and 12 months after the Sichuan earthquake in China. Journal of Child Psychology and Psychiatry, 55(1), 31-38.

Zhang, Y., Zhang, J., Zhu, S., Du, C., \& Zhang, W. (2015). Prevalence and predictors of somatic symptoms among child and adolescents with probable posttraumatic stress disorder: a cross-sectional study conducted in 21 primary and secondary schools after an earthquake. PloS one, 10(9), e0137101. 